\title{
FGFR1 Gene Alteration Positive
}

National Cancer Institute

\section{Source}

National Cancer Institute. FGFR1 Gene Alteration Positive. NCI Thesaurus. Code C150614.

An indication that mutation, overexpression, fusion or rearrangement involving the FGFR1 gene has been detected in a sample. 